\title{
NURSING PRACTICE \\ REALITY OR DREAM
}

\section{Paper presented at the symposium Nursing in the Eighties, Rand Afrikaans University. \\ CHARLOTTE SEARLE}

\section{OPSOMMING}

Hier te lande is verpleegpraktyk 'n wetlike en maatskaplike werklikheid. Sommiges glo egter dat die term verpleegpraktyk net op die verpleegkundige in private praktyk betrekking het.

Verpleegkundiges geniet sedert 1891 wetlike praktisyn-status. Hulle is praktisyns in eie reg, ongeag die gesondheidsopset waarin hulle werk. Verskeie faktore aan die begin van die eeu het daartoe bygedra dat die verpleegkundige 'n ondergeskikte houding teenoor die mediese praktisyn aangeneem het. Vandag is dit moeilik om sommiges te oorreed dat hulle ten volle verantwoordbaar en mede-verantwoordelik vir pasiëntsorg is.

Dit is elke verpleegbestuurder se plig om te verseker dat die geregistreerde verpleegkundiges op haar personeel as professionele praktisyns, in die ware sin van die woord, funksioneer.

\section{INTRODUCTION}

For the purpose of this article, the term nursing practice excludes midwifery practice. The debate as to whether a nurse is a practitioner or not centres on the nurse and not on the midwife. Both legally and by customary practice, the midwife in South Africa has enjoyed the status of a practitioner since 1652 , whilst the nurse has only been recognised as a legal practitioner since 1891 .

\section{NURSING PRACTICE A REALITY}

The thesis of this article is that nursing practice is a legal and a social reality, and is definitely not a dream. It is a phenomenon that exists as an entrenched part of the social structure of this country and is recognised in law. What we make of practice determines the reality of it from the viewpoint of the community.

\section{THE CONCEPT PRACTICE}

Just what is meant by practice when used in a professional context? Webster's dictionary describes practice as follows: to put knowledge into practice, to work at, or to follow a profession. The Reader's Digest illustrated Dictionary refers to practice when used in a professional context as: the exercise of an occupation or profession.

Prof Dr C. Searle, BA (SocSc) (Unisa), MA(UP), DPhil(UP), RN, RM, CHN, NEduc, NAdmin.

Head, Department of Nursing, University of South Africa.
Neither of these authoritative sources define how the occupation or profession is to be practised. In other words the concepts inherent in these definitions apply equally to private practice and to practice in an employment situation. Private practice for all professionals was essentially an 18th and 19th Century phenomenon. Today, worldwide, more professionals practice within an employment situation than out of it.

\section{Some misunderstanding evident}

There appears to be a measure of misunderstanding about what is meant by nursing practice. Some American nursing literature views practice in the way it is done in South Africa (A.N.A., 1973. Preface).

However, some authors appear to adopt the standpoint that one practises nursing when one is engaged in private practice, that is when one conducts an independent nursing business. One treats those patients and advises clients referred to the nurse practitioner by a medical practitioner, or those who have come without referral to obtain a specific type of nursing care. (Jacox and Norris, 1977: pp xiii, 3: 21,22,23,25, $193,198,207)$. There is frequent reference to the emergence of a new category of nurse known as a nurse practitioner.

\section{Need to be specific}

There is a need to be clear in one's writings and discussions about the meaning of nursing practice within the national context. It is desirable that the $\mathrm{S} \mathrm{A}$
Nursing Council should publish a national statement in which it is made clear that the only valid definition of nursing practice for South African purposes is that which is provided in the Nursing Act. However, it appears that nurses do not study the Nursing Act so as to clarify their practitioner status.

\section{Three points of view on the topic of this paper}

The question nursing practice, dream or reality? can be viewed in three ways, namely: the legality of nursing practice; fulfilling a practitioner role, irrespective of the health care setting in which the nurse functions, and the reality of practice, from a care point of view.

\section{THE LEGALITY OF NURSING PRACTICE}

It is adumbrated that the nursing practice concept in South Africa is a legally entrenched one that has the same validity, and hence the same reality, as the practice of the medical practitioner.

\section{Legal practioner status - 1891}

The legal practitioner status of the nurse in South Africa dates back to 1891, when the provisions of the Medical and Pharmacy Act No 34 of 1891 provided for the registration of medical practitioners, dentists, apothecaries (including chemists and druggists), midwives and nurses on the same register, though in different sections there-of. Section 47 of this Act specifically provided that registered persons who were 
found guilty of infamous or disgraceful conduct in any professional or other respect, after due enquiry by the Council, were to have their names removed from the register, subject to approval by the governor. Once this had been done they were not entitled to practise their profession.

Inherent in every section of this first Act which provided for the registration of these five categories of health practitioner was the principle that the person observes the law and its regulations to retain the right to practise his/her profession.

The Medical and Pharmacy Act of 1891 clearly showed that registered health professionals were dependent on observance of the law to remain in practice. Nowhere was there any reference that the nurse was dependent on the orders of the doctor to practice her profession. Personal responsibility and accountability, which lies at the core of professional practice, was inherent in every aspect of the Act and its regulations.

Section 31 of this Act specifically provided for the withdrawal or cancellation of a certificate of registration granted to a trained nurse if it was proved that the holder was grossly incompetent, or had been guilty of such unproper conduct as in the opinion of the Council rendered it inadvisable that she should continue to practise as a trained nurse.

Nowhere in the regulations gazetted under this act did it appear that the nurse could only practise her profession in an employment situation, or under the supervision of a doctor. The regulations treated her as an independent practitioner on the same lines as the. other four categories of persons registered in 1891 .

\section{PRIVATE PRACTICE}

It could not be otherwise. There were very few hospitals at that time. The major part of the health care was provided by nurses in the homes of the patients. These were self-employed nurses or nurses in private practice. Wherever medical assistance was available they worked in close collaboration with the family medical practitioner in the same way as they worked closely with the doctor in the hospital situation. Mutual interdependence was well entrenched.
Up to the beginning of the S A War 1899-1902, the majority of registered nurses were in private practice. Some had rooms in their homes from which they provided a service, others undertook private nursing, and some established small private nursing homes. This group of nurses established a network of small hospitals and of home care facilities which became the foundation of the health services which exist today. The practice of these private nursing practitioners helped to broaden the scope and range of medical practice.

\section{Independent functions}

At the same time institutional nursing practice was entrenching itself. A study of letters, documents, diaries, and books written by medical practioners indicate that by the end of the 19th century, the trained nurse in Southern Africa was established as a registered practitioner with a whole range of independent functions. These were:

- supervision of the patient and his immediate environment

- observation of the signs, symptoms and reactions experienced by the patient

- recording of symptoms, signs, reactions and treatment and care given

- supervision and direction of subordinate personnel serving the patient's needs

- co-ordination of the services of other workers who served the patient's needs

- planning and implementing of independent patient care activities such as the following: nursing care as well as supportive care; maintenance of personal and environmental hygiene directly associated with patient care; health education; assistance with social services

- personal responsibility and accountability for all her own acts and omissions including the carrying out of any prescription or request from the patient's doctor, provided this was within her range of competence, was legal, clear, accurate and not against the policy of the authority who had a contractual relationship with the patient for the safety of his person, his name and the property he brought with him on admission to the hospital. She had the right to refuse to co-operate with the doctor if such co-operation was against her religious beliefs and had a clear duty to protect the patient from illegal and incompetent health care, and from the medico-legal hazards found in hospitals.

\section{Legislation in the other colonies}

Legislation enacted in Natal in 1899 was similar to that enacted in the Cape. It is interesting to note that when Natal commenced the first training of nurses in 1890 , the regulations of the hospital provided that the probationer nurses had to give an undertaking that they would follow meticulously the orders of the doctors, and be subject to them at all times. This provision was not entrenched in the first law and regulations which authorised state registraion of nurses and midwives in Natal. Nevertheless we may presume that this concept was carried forward into the 20th Century.

After the S A War 1899-1902, the Transvaal and Orange River Colonies enacted legislation similar to the Medical and Pharmacy Act of 1891. It is interesting to note that the word medical was considered a generic word which included medical practitioners, dentists, nurses and midwives.

It is clear therefore that by the beginning of the 20th Century, all registered nurses in the colonies now constituting the Republic of South Africa were practitioners in their own right - no matter where they worked, in private practice, in hospitals, in the military services, or in doctor's consulting room. On the grounds of professional practitioner status the qualified nurses were given officer status during the South African war 1899-1902.

If this was the status of the nurse at the turn of the Century what went wrong? This question is asked because for many years during the twentieth century nurses subjected themselves to a situation where they negated their legal rights as practitioners. Yet legally they were involved in a co-operative practice situation, with both doctor and nurse, jointly and separately responsible for their patient.

The nurse practised her profession within the ambit of statutory laws and regulations, the common law, and the unwritten code of her profession - yet she abrogated her status as a practitioner. 


\section{Factors contributing to a sub- servient attitude}

A factor of major importance in the changing attitudes of the nurse, attitudes which made her subservient to the doctor (even if the law did not place her in such a position), was the advent of the South African War 1899-1902. Large numbers of nurses from the Poor Law hospitals in Britain served in the war. Many remained in this country to help with the reconstruction of the health services. They became the matrons and sisters in the hospitals.

The British pattern of nursing became established practice. At that time Britain had not yet acquired legislation to regulate nursing practice. A new concept in doctor-nurse relationships became entrenched in South Africa. The concept of the nurse as a practitioner in her own right disappeared for a time. The nurse was in the hospital to carry out the doctor's orders.

At the same time successive economic recessions is cause nurses to seek large scale employment in hospitals where the bureaucratic machine and fear of job losses during a time of great financial hardship smothered ideas of independent professional practice.

At the same time nursing education developed as a by-product of hospitalisation. Nursing education was geared to the requirements of the bureaucratic system and the orders of the doctor

Lectures in the theory of nursing amounted to a study of the basic sciences and of diseases. These lectures were given by doctors. The matrons and sisters gave demonstrations of the procedures used in nursing. There was no true preparation of a professional practitioner.

Qualified nurse tutors were introduced in the early twenties, but they had received their education overseas in a milieu where the philosophy of doctor supremacy in the nurse-doctor relationship was rampant. As a result of all this, the education of several generations of South African nurses reflected the concept that the nurse had a dependent function on the doctor, and that the nurse (as opposed to the midwife) was not a practitioner.

Yet, as late as 1944, the certificate issued by the S A Medical Council to a registered nurse clearly stated that she was competent to practise as a medical and surgical nurse.
The concept of the nurse as a practitioner and the principle of professional practice are securely entrenched in the Nursing Act No 50 of 1978, and in the Nursing Acts preceding this.

Despite these legal provisions it has been a dispiriting task to make some nurses realise that they are legal practitioners, fully accountable for their own acts and omissions, with a joint responsibility with the doctor for patient care.

\section{FULFILLING THE ROLE OF A PRACTITIONER IRRESPEC- TIVE OF THE HEALTH CARE SETTING}

The law empowers the nurse to practise her profession in any type of health care situation. The parameters of such professional practice are competence, authority, responsibility, accountability, independent decision making, collaboration, facilitation, advocacy, nursing diagnosis, planning of nursing care and recording of actions on behalf of the patient/client.

One of the constraints in nursing practice in the hospital situation is the fact that we name the division responsible for nursing care as the nursing service department. Emphasis falls heavily on the concept service, in a bureaucratic sense. It is an integral aspect of a bureaucratic hierarchial organisation. This constitutes a threat to professional responsibilities and professional practice concepts. Take a close look at the nursing service concept as evinced in many of our hospitals.

It is not service to the patient but service to the service organisation that lies at the centre of nursing practice in many of our large institutions. It is the duty of every nurse manager to ensure that the registered nurses on her personnel are true practitioners. They must be freed from the excessive bureaucratic restraints that make them service automatons, and they must be helped to act as fully accountable practitioners.

It is ironical that the only time at which the health care authorities stress the professional accountability of the nurse is when a claim for damages is lodged by a patient. Is it not time that we label the existing nursing service divisions, as nursing care divisions so as to ensure that the emphasis falls on the professional practice aspects of the nurses' contribution to patient care, and the centrality of the care to the patient is emphasised.
The concept of nursing practice and of a nurse practitioner was undermined by matrons in the organisational hierarchy. Only the nurse manager can now lift nursing practice to its rightful status in the health care institutions. The quality of the nurse managers and their insight into the management of professionals can resolve this contentious problem.

This is a vitally important problem. Nurse leaders have a duty to ensure that their professional nursing personnel practice as professionals. This is the whole justification for the nurse manager being a professional nurse for, presumably, she knows what the professional practice of a nurse entails. If she continues to negate this vitally important dimension of her work the end result will be that it will not be necessary for a professional nurse to hold the post of nurse manager - for nurses will not be concerned with professional practice, but only with carrying out the rules of the institution and the orders of the doctor. The choice is ours. Will we make professional practice a reality, or will we live in a dream world and continue to pay lip service to the concept of professional practice and practitioner status?

\section{THE REALITY OF NURSING PRACTICE}

Whilst the legality of nursing practice is very much a reality, can we say the same of the reality of nursing practice? How nursing practice is carried out constitutes an experience for the patient and his family. Is the reality of nursing practice what the patient expects?

We all know that some neglect of patients occurs daily and that slovenly, indifferent and even ignorant practice exists at times. We see untidy nurses in the wards and on the streets. Are we facing facts and admitting that our nurs ing practice is not all it should be in all centres?

Is the profession aware of the number of nurses who annually face disciplinary action by the $\mathrm{S} A$ Nursing Council? Are all of us prepared to walk the extra mile when the need is great? How many of us share in the work of our professional association? Are we really professional practitioners if we disregard this vital element in our professional life? 